\title{
Gender Roles and Challenges of Small Scale Cashew Nut ProcessingEnterprise in Enugu North, Nigeria
}

\author{
I. A. Enwelu* \\ S. T. Ugwu \\ Ayogu C. J. \\ Ogbonna, 0. I. \\ Department of Agricultural Extension, University of Nigeria, Nsukka, Enugu State, Nigeria
}

\section{Doi:10.5901/jesr.2014.v4n7p74}

\section{Abstract}

\begin{abstract}
Small scale cashew nut processing enterprise is important in meeting the needs of the local processors and strategic in the current transformation agenda of the government. The study examined the gender roles and challenges of small scale cashew nut processing enterprise in Enugu North Senatorial zone of Enugu State. Seventy two small scale cashew nut processors were identified and interviewed to elicit information for the study. The study revealed that youths on the whole were found to be more effective in most of the activities of cashew nut processing namely packaging ( $M=2.0)$, grading ( $M=1.90)$, sizing $(M=1.50$ and cleaning $(M=1.50)$. On the other hand, men played more effective role in two processing activities- shelling $(M=2.0)$ and peeling $(M=2.0)$ while women played more effective role only in one activity- roasting/frying $(M=1.80)$. It was found that all the respondents (100.0\%) were still using local processing method like open pan roasting. About $19.0 \%$ of the respondents processed $3-5 \mathrm{~kg}$ per day while $12.4 \%, 2.2 \%$ and $1.4 \%$ processed $6-8 \mathrm{~kg}, 9-11 \mathrm{~kg}$ and $12-14 \mathrm{~kg}$ per day respectively. The challenges of small scale cashew nut processors were chemical burns $(M=3.86)$, damage of kernels by fire through non regulation of heat $(M=3.67)$, high cost of kernels ( $M=3.57)$ and excess heat affecting the body. The study concluded that the contribution of cashew nut processing enterprise to the transformation agenda was hampered by the use of local processing equipment which also adversely affected the livelihood survival of local processors.
\end{abstract}

Keywords: Cashew nut, challenges, enterprise, gender roles, processing, small scale

\section{Introduction}

Cashew (Anacardium Occidentale L.) was introduced into Nigeria between $15^{\text {th }}$ and $16^{\text {th }}$ centuries by the Portuguese explorers (Ventakarama, 1996 and Togun, 1997). Cashew nuts produced by the plant are very important fruit crop. They are popular treats found on grocery and health food store shelves across the world. Locally they are eaten as food after processing/frying and usually seen in pale, ivory coloured/coated white nuts. The nuts are packed with energy containing about 1 gramme per ounce of energy while the fleshy succulent parts attached to the nuts are eaten raw or processed into wine/juice and other beverages for human consumption (Hanlon, 2000).

Apart from being a source of useful products and by-products for food, medicine and industrial applications, cashew tree also gives a useful shade, acts as ornamental and alley tree and is suitable for control of soil erosion, particularly for the protection of watersheds and dams (Ezeagu, 2002). Prior to cultivation and production of cashew in Nigeria in 1950s, the plant had survived in the wild for more than four centuries. The long term neglect of cashew industry in favour of oil production and exploration left Nigeria behind in competing for the global market worth of \$1 billion. Research into processing, marketing and economy of cashew commenced in 1972 by Cocoa Research Institute of Nigeria in Food and Agricultural Organization (FAO, 2000)

Cashew nuts are very rich source of minerals. Minerals especially manganese, potassium, copper, iron, magnesium, zinc and selenium are concentrated in the nuts. A handful of cashew nuts a day in the diet would provide enough of these minerals and prevent diseases caused by their deficiency. Selenium found in cashew nut is an important micronutrient, which functions as co-factor for antioxidant enzymes such as Glutathione peroxides,one of the most powerful antioxidant in the body (www.nutrition-and-you.com/cashew-nut.html).

The income of cashew nut is enhanced through proper and efficient processing. The main objective of processing 
is to remove the valuable cashew kernels from the shells with as little damages as possible. This is because whole nuts command higher prices than the broken ones. In spite of this well known fact, cashew nuts are processed locally using manual techniques like frying ovens constructed with metal such as open pans and open drums by some households (men, women and children). Local cashew nut processors usually made up of youths, women and men are engaged in this enterprise as a means of livelihood. Through this method, most of the products are consumed locally in rural, semi and urban areas. The future of the enterprise lies in secondary processing stage, which entails a higher level of transformation that targets mainly export markets and local/urban markets too. The technology systems entail nut cleaning, calibration and storage by grade, washing and humidification, roasting, centrifugation and cooling. They also involve shelling and kernel shell separation, kernel drying, peeling, grading, sorting and packing for market (Ezeagu, 2002).

The local processes involved in cashew nut processing are labour intensive requiring vigorous activities that are time consuming. Local method of processing requires many hands (both household family labour and hired labour). The quality of cashew nut obtained through this method is poor. The nuts are not standardized presenting lots of differences in size, finishing and roasting.

In the face of the foregoing, the study sought to: ascertain the socio-economic status of small-scale cashew nut processors; determine roles performed by men, women and youth in processing of cashew nuts; examine cashew nut processing methods and quantity processed per day; and determine challenges facing small-scale cashew nut processors (enterprise).

\section{Methodology}

The study was carried out in Enugu North Senatorial Zone of Enugu State, Nigeria. The population of the study comprised all cashew nut farmers/processors and others engaged in cashew nut processing in the zone. Out of seven local government areas (LGAs) in the zone, three were randomly selected namely Nsukka, Igbo-etiti and Udenu. A preliminary survey was conducted in each of the selected LGA to identify town/village communities engaged in cashew nut processing. Two town communities involved in cashew nut processing were purposively selected in each LGA. A list of 20 cashew nut processors (men, women and youth) was compiled in the village community selected from each town community. From the list compiled, 12 small scale processors (made up of 4 men, 4 women and 4 youths) were randomly selected which gave a total sample size of 72 respondents. Data were collected through the use of interview schedule and analysed using percentage and mean scores.

\section{Results and Discussion}

\subsection{Socio-economic characteristics of small-scale cashew nut processors}

In Table 1 about $28.0 \%$ of the respondents had no formal education and majority (72.2\%) had 1-9 years experience in cashew nut processing. The mean age of the processors was 31 years and greater proportion (43.1\%) was married. The average household size was six with $54.2 \%$ of the respondents making a monthly income of between $\$ 10,000.00$ \#14,999.00 from cashew nut processing. The greater portion (47.2\%) of the respondents belonged to farmers' organization while majority (86.1\%) made use of family labour.

The interest of youths in cashew nut processing makes the enterprise strategic in the implementation of government transformation agenda especially in the area of employment generation. In Kenya, Cashew Nut Limited was processing 60 tons per day and employing a labour force of 2000 people (1200 women and 800 men) http://www.scribd.com/ozorhyacinth The respondents were fairly educated and as such can bring to bear new technologies in cashew nut processing. The cashew nut processors were only fairly experienced with about $72.0 \%$ spending 1-9 years in the enterprise. This means that they have to depend on the older processors in times of difficulty in some aspects of processing activities. The high dependence on family labour (86.1\%) is an indication of low level of processing operation. 
Table 1: Percentage distribution of socio-economic characteristics of cashew nut processors

\begin{tabular}{|c|c|c|c|}
\hline Socio-economic characteristics & Frequency & Percentage & $\operatorname{Mean}(\bar{x})$ \\
\hline \multicolumn{4}{|l|}{ Age } \\
\hline $20-29$ & 19 & 26.4 & \\
\hline $30-39$ & 18 & 25.0 & 31.0 \\
\hline $40-49$ & 18 & 25.0 & \\
\hline 50 and above & 17 & 23.6 & \\
\hline \multicolumn{4}{|l|}{ Marital status } \\
\hline Single & 23 & 31.9 & \\
\hline Married & 31 & 43.1 & \\
\hline Divorced/separated & 10 & 13.9 & \\
\hline Widowed & 8 & 11.1 & \\
\hline \multicolumn{4}{|l|}{ Educational qualification } \\
\hline No formal education & 20 & 27.8 & \\
\hline Primary & 27 & 37.5 & \\
\hline Secondary & 21 & 29.2 & \\
\hline OND/HND/Degree & 4 & 5.5 & \\
\hline \multicolumn{4}{|l|}{ Monthly income from cashew } \\
\hline$\# 0.00-\approx 4,999.00$ & 11 & 15.3 & \\
\hline$\$ 5,000.00-\$ 9,999.00$ & 7 & 9.7 & \\
\hline$\# 10,000.00$ - $\# 14,999.00$ & 39 & 54.2 & $\$ 12,500.00$ \\
\hline$\# 15,000.00$ and above & 15 & 20.8 & \\
\hline \multicolumn{4}{|l|}{ Household size } \\
\hline $0-4$ & 23 & 31.9 & \\
\hline $5-9$ & 34 & 47.2 & 6 \\
\hline $10-14$ & 15 & 20.8 & \\
\hline \multicolumn{4}{|l|}{ Processing experience (Years) } \\
\hline $1-9$ & 52 & 72.2 & \\
\hline 10 and above & 20 & 27.8 & \\
\hline \multicolumn{4}{|l|}{ Social organization belonged } \\
\hline Farm organization & 34 & 47.2 & \\
\hline Religious organization & 27 & 37.5 & \\
\hline Social club & 9 & 12.5 & \\
\hline None & 2 & 2.8 & \\
\hline \multicolumn{4}{|l|}{ Source of labour } \\
\hline Hired labour & 10 & 13.9 & \\
\hline Family labour & 62 & 86.1 & \\
\hline
\end{tabular}

\subsection{Gender roles' effectiveness in cashew nut processing}

Table 2 reveals that there were effective role performances across gender and age. However, youths on the whole were found to be more effective in most of the activities of cashew nut processing namely packaging $(\bar{x}=2.0)$, grading $(\bar{x}$ $=1.90)$, sizing $(\bar{x}=1.50)$ and cleaning $(\bar{x}=1.50)$. On the other hand, men played more effective role in two processing activities- shelling $(\bar{x}=2.0)$ and peeling $(\bar{x}=2.0)$ while women played more effective role only in one activityroasting/frying ( $\bar{x}=1.80)$.

The effectiveness of youths in cashew nut processing underscores the importance of cashew nut processing enterprise in employment generation. The transformation of this sector will minimise rural-urban migration and improve the standard of living of rural dwellers including the youths. Although women played major role in only one activity but that activity is pivotal to the processing enterprise because it sets the stage for the subsequent processing activities. 
Table 2: Mean score distribution of gender roles' effectiveness in cashew nutprocessing

\begin{tabular}{|c|c|c|c|}
\hline Operations & $\operatorname{Men}(\bar{x})$ & Women $(\bar{x})$ & Youths $(\bar{x})$ \\
\hline Cleaning & $1.42^{\star}$ & $1.20^{*}$ & $1.50^{*}$ \\
\hline Sizing & $1.00^{*}$ & $1.36^{*}$ & $1.50^{*}$ \\
\hline Roasting/frying & - & $1.80 *$ & $1.57^{*}$ \\
\hline Shelling & $2.00^{*}$ & $1.60 *$ & $1.92^{*}$ \\
\hline Peeling & $2.00^{*}$ & $1.67^{*}$ & $1.73^{*}$ \\
\hline Grading & $1.00 *$ & $1.72^{\star}$ & $1.90 *$ \\
\hline Packaging & $1.50 *$ & $1.72^{\star}$ & $2.00 *$ \\
\hline
\end{tabular}

Cut-off $\bar{x}=1{ }^{*}=1$ and above

\subsection{Cashew nut processing methods and quantity processed per day}

Entries in Table 3 show that all the respondents (100.0\%) were using local processing method like open pan roasting. About $7.0 \%$ were still using local processing by shell cracking while no processor was using small cottage processing technique. About $19.0 \%$ of the respondents processed $3-5 \mathrm{~kg}$ per day while $12.4 \%, 2.2 \%$ and $1.4 \%$ processed $6-8 \mathrm{~kg}, 9$ $11 \mathrm{~kg}$ and $12-14 \mathrm{~kg}$ per day respectively.

The use of local processing method in cashew processing enterprise is a reflection of the present status of the industry. This method can not even meet the local demand of cashew nut products in the zone or meet the minimum requirement for export market. In Kenya small-scale processors can only handle about 10, 000 tons which cannot even meet export quality standard (http://www.scribd.com/ozorhyacinth). In spite of many years of cashew nut development in Enugu State, the zone (Enugu North Senatorial Zone) is yet to move to secondary processing stage which entails a higher level of transformation that targets mainly exports markets and local/urban markets. The Premier cashew processing industry" at Oghe, in Ezeagu LGA of Enugu State, was the first established processing factory for export but was closed down due to management problem (Ezeagu, 2002). The quantity $(\mathrm{kg})$ produced per day is uneconomical and can hardly meet the daily requirements of processors.

Table 3: Percentage distribution of processing methods and quantity processed per day

\begin{tabular}{lcc}
\hline Processing methods & Frequency & Percentage (\%) \\
\hline Local processing by shell cracking & 5 & 6.9 \\
Local processing by open pan & 72 & 100.0 \\
Small cottage processing & - & - \\
Quantity processed per day per kg & & \\
3-5 & 39 & 54.2 \\
6-8 & 26 & 36.0 \\
$9-15$ & 4 & 5.6 \\
$16-18$ & 3 & 4.2 \\
\hline
\end{tabular}

\subsection{Challenges of small-scale cashew nut processors}

Table 4 highlights the major challenges of small-scale cashew nut processing enterprise, namely: use of local processing equipment $(\bar{x}=3.86)$; poor quality of cashew nut products ( $\bar{x}=3.67)$; lack of capital $(\bar{x}=3.57)$; cashew nut processing hazards $(\bar{x}=3.26)$; and scarcity of raw materials $(\bar{x}=2.79)$. However, the respondents did not consider poor extension education ( $\bar{x}=1.26$ ), poor transportation $(\bar{x}=1.37)$, unavailability of labour $(\bar{x}=1.43)$ etc as major challenges in the zone.

The major challenge facing small-scale cashew nut processors is the use of inefficient local processing tools. According to Ezeagu (2002), the quality of cashew nuts obtained through this processing method is poor. The nuts are not standardized, presenting lots of differences in size, finishing and roasting. The use of local processing tools gives rise to the challenge of poor quality of products with its attendant hazards such as burning of hands and excessive heat to the body. The poor quality of products will compound the challenge of lack of capital because only quality products attract better prices. High quality cashew nut products attract prices ranging between US $\$ 2-3$ per pack of 200grams (Ezeagu, 2002). However, the challenge of lack of cashew nuts (raw material) seems to be ridiculous in a state said be among the largest producers of cashew. Major cashew growing areas in Nigeria are, by order of importance: Enugu, Abia, Imo, 
Anambra, Ebonyi and Cross River States in the eastern part of the country; Oyo, Osun, Ondo, Ekiti and Ogun States in the Western part, as well as Kwara, Kogi, Nassarawa, Benue, Taraba, Niger and FCT in the Middle Belt and also Sokoto and Kebbi States in the North West part of the country (Ezeagu, 2002). Therefore, the government transformation agenda in agricultural sector is recommended to revisit cashew nut industry in Enugu State.

Table 4: Challenges of small-scale cashew nut processing

\begin{tabular}{lc}
\hline Processing challenges & Mean $(\bar{x})$ \\
\hline Lack of capital & $3.57^{*}$ \\
Scarcity of cashew nuts (raw material) & $2.79^{\star}$ \\
Unavailability of labour & 1.43 \\
High cost of labour & 2.24 \\
Poor storage facilities & 2.23 \\
Poor extension education & 1.26 \\
Poor transportation & 1.37 \\
Local processing equipment & $3.86^{\star}$ \\
Cashew nut processing hazards (chemical burns) & $3.26^{\star}$ \\
Poor quality of cashew nut products & $3.67^{\star}$ \\
\hline
\end{tabular}

Cut-off $\bar{x}=2.5 *=2.5$ and above

\section{Conclusion}

The study established that youths on the whole were more effective in most of the activities of cashew nut processing namely packaging, grading, sizing and cleaning. It was also found that all the respondents (across gender) were still using local processing method like open pan roasting resulting to uneconomic quantity processed per day. Therefore, the study also concluded that the contribution of cashew nut processing enterprise to the transformation agenda was hampered by the use of local processing equipment which also adversely affects the livelihood survival of local processors. The study established that the challenges of small scale cashew nut processors were chemical burns by cashew nut chemicals (CNSL), damage of kernels by fire through non regulation of heat, high cost of kernels, excess heat affecting the body while roasting/frying and poor quality of kernels.

\section{References}

Akinwale, S. A. and Esan, E. B. (1989). Advance in cashew breeding in Nigeria in Progress. In Tree Crop Research, $2^{\text {nd }}$ edition of CRIN, Ibadan, Nigeria, pp. 166-1674

Ezeagu, W. (2002). Assessment of the situation and development prospects for thecashew sector, a report carried out on behalf of the International Trade Center UNCTAD/WTO (ITC) and funded by the ITC Global Trust Fund under project

FAO (2000). Production data base http:apps.org.page/collection

Hanlon, J. (2000). Power without responsibility- the World Bank and Mozambiquancashew nuts. Review of African political economy: 27(88)

Igbokwe, A. D. (1985). Biology and control of pests and diseases of cashew, a paper presented at a symposium to mark the $21^{\text {st }}$ anniversary of establishment of CRIN, Ibadan, Nigeria.

Osinem, E. C. (2005). Environmental education in agriculture, Enugu: Cheston Agency Ltd, pp. 157-161

Nugawela, P. and Oroh, R (2005). Cashew Sub-sector Strategic Framework Using

Cashew Sector Markets for Pro-poor Growth in Nigeria. PrOpCom Monograph Series \# 1 Funding for this programme is provided by the United Kingdom's Department for International Development (DFID)

Togun, A. (1997). A review of prospects of cashew industry p.39

Ventakaramah, T. M. (1996). Cashew nut production and processing: Nigeria agronomic aspect of cashew nut production, unpublished paper submitted to CRIN, p.39 